\title{
A picky palate? The host plant selection of an endangered June beetle
}

\author{
Kirsten E. Hill • Rachel O’Malley
}

Received: 5 July 2009/ Accepted: 25 November 2009/Published online: 8 December 2009

(C) The Author(s) 2009. This article is published with open access at Springerlink.com

\begin{abstract}
Precise information about endangered species, in particular identifying their resources requirements, is needed to identify areas that might support populations. Little is known about the endangered Mount Hermon June Beetle (Polyphylla barbata) found only within Zayante soils region of Santa Cruz County, California. We investigated the beetle's host plant selection, habitat association and mating behavior between June 2004 and September 2005. We identified angiosperm and Pteridophyta phyla, and fungi within the frass pellets of Mount Hermon June Beetle larvae demonstrating that they are not specialist feeders but are microhabitat specialists. Larval species was confirmed by DNA analysis. Significant differences were found in vegetation assemblages between regions where the Mount Hermon June Beetle did and did not occur for Chorizanthe pungens var. hartwegiana, and bare ground.
\end{abstract}

Keywords Endangered insect - Polyphylla barbata . Frass · Generalist

\section{Introduction}

An endangered species cannot be protected until its food source has been identified and protected as part of the species habitat. Anecdotal information suggests that the federally endangered Mount Hermon June Beetle

\section{K. E. Hill $(\square)$}

Department of Environmental Science, Policy Management,

University of California, Berkeley, CA, USA

e-mail: kirhill@berkeley.edu

\section{R. O'Malley}

Department of Environmental Studies, San Jose State University, 100 Washington Square, San Jose, CA, USA
Polyphylla barbata (Cazier) is a specialist feeder, but without more quantitative research on food sources and habitat it requires, we cannot identify appropriate management practices to sustain this species (Arnold 1999; Hazeltine 1993; U.S. Fish and Wildlife 1997). To date, very little research has been conducted regarding most Polyphylla species food sources; research thus far has been focused on the adaptive radiation of various species in the genus (Arnett et al. 2002).

The Mount Hermon June Beetle is found only within the Zayante Sandhills of the Santa Cruz Mountains in the San Francisco Bay Area, a recognized biological diversity hot spot in which $50 \%$ of the species of arthropods listed by the U.S. government as endangered occurs (Connor et al. 2003). The Zayante Sandhills cover only $3 \%$ of Santa Cruz County, but support many rare and native plant species, and are considered to be "biological islands", distinctive areas where certain species thrive (U.S. Fish and Wildlife Service 1997). Prior to human disturbance, the Zayante Sandhills habitat covered 6,265 acres (Lee 1994). Approximately $40 \%$ of the Zayante Sandhills habitat has been lost to or altered by human activity (U.S. Fish and Wildlife Service 1997). Several rare and endangered species here are threatened by urban development, recreation sand mining, and other human activities. Recreational activities (e.g., off-road vehicles, horse back riding) within the Zayante soil increase its proneness to erosion and also result in compaction which may also disturb the beetle's life cycle.

We studied potential host plant(s) for the Mount Hermon June Beetle to aid conservation goals and management practices for policy-makers charged with biodiversity protection for the Sandhills. For the Mount Hermon June Beetle, a species that feeds only in its fossorial larval form, has a limited flight season, and as yet is morphologically 
unidentifiable in larval form, combined genetic and frass analysis were essential to evaluate host plant selection.

Natural history of the Mount Hermon June Beetle

Cazier (1938) initially described the Mount Hermon June Beetle, recognizing it as a distinct scarabaeidae species in the genus Polyphylla. In recognition of its limited distribution, the Mount Hermon June Beetle was listed as an endangered species in 1997 (U.S. Fish and Wildlife Service 1997). The Mount Hermon June Beetle is a small dark brown scarab beetle with fragmented and discontinuous white stripes of scales on its elytra (Fig. 1). It is distinguished from three other Polyphylla species that occur within regions of Ben Lomond, Felton, Mount Hermon, and Scotts Valley $\left(37^{\circ} 04^{\prime} 3515^{\prime \prime} \mathrm{N} 122^{\circ} 04^{\prime} 0790^{\prime \prime} \mathrm{W}\right)$ by dense, long erect hairs scattered randomly over the elytra and short erect hairs on the pygidium (last abdominal segment) (Young 1967, 1988). The males (20 mm long by $9.7 \mathrm{~mm}$ wide) are smaller than females $(22 \mathrm{~mm}$ by $12 \mathrm{~mm}$ ). The small mouthparts and limited flight period of the adults suggest that they do not feed as adults (Hazeltine 1993). Larval food plants of other Polyphylla species include conifers, shrubs, herbs, grasses (Young 1988; Van Steenwyk and Rough 1989) but are unknown for the Mount Hermon June Beetle (Hazeltine 1994, Russell 1994).

From May to August, during the Mount Hermon June Beetle's flight season, males emerge at dusk from the soil and underneath shrubs and herbaceous plants. The male Mount Hermon June Beetle has a very limited flight season and is most active between 20:00 and 22:00 between midMay and mid-August just after sunset while the air above the ground is still warm. Male flight activity may be limited by temperature, wind, and may also be affected by dense

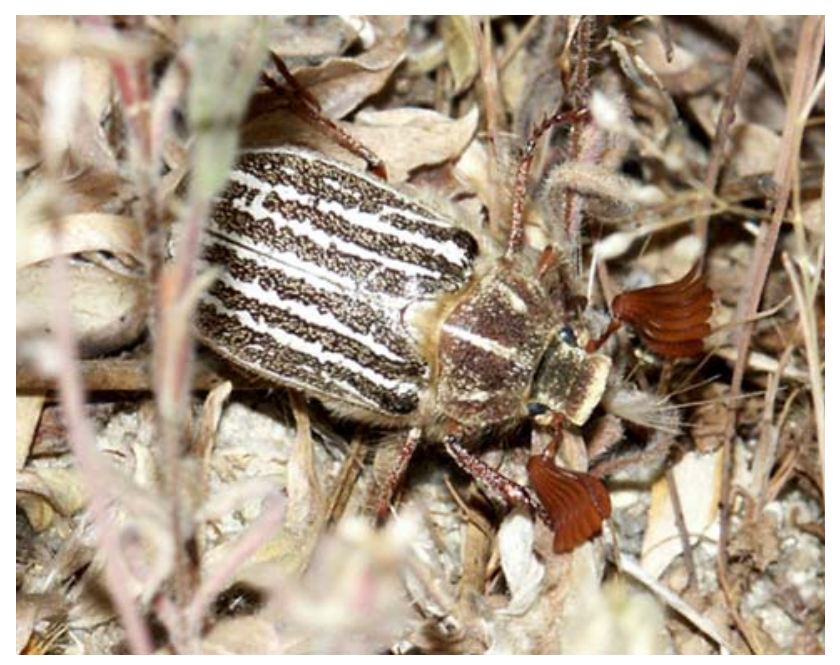

Fig. 1 The Mount Hermon June Beetle (male). Photograph of the Mount Hermon June Beetle used with permission from Jodi McGraw cloud cover. Their wings make a distinctive crackling noise as they fly up through the vegetation. They are often found flying low to the ground seeking the source of female pheromones and swarming in areas of a female burrows (Arnold 1999). Once a female is located, several males often compete for her. The successful male copulates with the female for 2-10 min as the female burrows into the soil (K. Hill, personal observation).

\section{Habitat}

The Zayante soils, derived from loosely consolidated Micocene marine sand deposits of the Santa Margarita formation (Marangio 1985), are of little agriculture value, as they are nutrient poor and "excessively drained" (U.S.D.A. Soil Conservation Sciences 1980). The distinctive character of the soil creates a microclimate that is warmer and drier than surrounding regions that typically support redwood forests (Griffin 1964). Over 90 species of plants found in the Zayante Sandhills flora have been identified as "Sandhills specialty plants" and are grouped in one of the following categories; endemic, disjunct population, coastal relict, threatened, locally unique, or undescribed ecotypes (McGraw 2004). Not only are many plants unique to the Sandhills community, but variation has also been found to occur within the Sandhills flora species distribution as a result of spatial variation and the variety of interacting biotic and abiotic components (McGraw 2004). The ecosystem supports several endemic flora and fauna and disjunct populations of species, including the ponderosa pine (Pinus ponderosa) (Griffin 1964).

Although Polyphylla beetle species are found worldwide, distribution of the genus is typically fragmented. Many of the species occur in isolated, sandy environmental refugia. In total, thirty-one species are found in America, north of Mexico (Arnett et al. 2002). From last count, 30\% of these species are broadly distributed (found in three or more states), $18 \%$ of species are narrowly distributed (found in two or three states) and the remaining 54\% are endemic to one or two localities (Young 1988). Many isolated Polyphylla species, including the Mount Hermon June Beetle are dimorphic, with a flightless female. Young (1988) noted in his Monograph of the Genus Polyphylla that these scarabs diverge fairly rapidly as isolated inbred populations become restricted to one sand dune complex or one mountain top.

Current information about the Mount Hermon June Beetle host plant selection and microhabitat usage is limited. Similar to many Polyphylla species, the Mount Hermon June Beetle has a very narrow habitat distribution and prefers sand, grass and conifer associations like those found in the Zayante Sandhills (Borror et al. 1976). The Mount Hermon June Beetle's habitat includes open, sparsely vegetated areas of this region described as ponderosa 
pine chaparral habitat, ponderosa forest, and northern maritime chaparral (Arnold 1999, 2004; Hazeltine 1993; Russell 1994). Conservation management for the species has used Ponderosa pine as an indicator of the Mount Hermon June Beetle's' habitat (Arnold 2004). The scientists who have observed the Mount Hermon June Beetle's flight patterns and burrow locations suggest that it may have one, few or several food sources, including possibly the roots of ponderosa pine (Pinus ponderosa), grasses, monkey flower (Mimulus sp.), oak (Quercus sp.), silver leaf manzanita (Arctostaphlos silvicolai), and or bracken fern (Pteridium aquilinum) (see Arnold 1999; Hazeltine 1993; Russell 1994). Some previous study of the June beetle suggests that the larvae are generalists and/or that they feed on grass roots, but has been inconclusive about host plant selection and habitat requirements (Hazeltine 1994; Russell 1994). It has also been suggested that Mount Hermon June Beetle host plant selection is limited to Ponderosa pine or plants in areas within a few hundred feet of Ponderosa pine trees (Arnold 2004).

\section{Research objectives}

The Recovery Plan for the endangered Mount Hermon June Beetle recommends that research focus on the beetle's habitat requirements for long-term survival (e.g., feeding behavior requirements; requirements for larval and adult stages) (U.S. Fish and Wildlife Service 1998). Female habitat and larval host plant(s) are likely crucial. The Mount Hermon June Beetle is known to eat only in its fossorial, larval stage. Although much information is required to manage and protect an endangered species (i.e., predators, parasites, thermoregulatory limitations, etc.,) the goal of the research was establish the feeding range of the larvae and the microhabitat/habitat requirements of the adults with a view to better aid conservation efforts within the limited remaining habitat of the Zayante sandhills. This also included establishing female burrow distance from the nearest Ponderosa pine as it was considered a habitat indicator.

\section{Materials and methods}

Research site

Quail Hollow Quarry is a 89 hectare sand quarry pit that supports eight plant communities: northern maritime chaparral, successional scrub, central coast scrub, maritime coast range ponderosa pine forest, hardwood-conifer woodland, sand parkland, central coast live oak riparian forest, and central arroyo willow riparian forest (Granite Rock Company 1998). The quarry provides typical habitat for the Mount Hermon June Beetle. Many of the plant communities are intergraded, as well as degraded, especially in the Future Mining Area of Quail Hollow Quarry (O'Malley et al. 2003). The Quarry is located approximately 35 miles south and west of San Jose near Felton, California just south of East Zayante Road. The area designated for future mining includes disturbed portions and other portions where natural habitats are more or less intact.

Study design and procedures

\section{Habitat description}

Mount Hermon June Beetle potential habitat was monitored during 44 observations periods between 2004 and 2005; Mount Hermon June Beetles were observed mating during 7 nights in 2004 and 10 nights in 2005. Surveys were conducted between 19:00 and 22:00 on a weekly basis between mid-May and mid-August. All flight activity was monitored with flashlights. Due to the nature of the rough terrain within the Future Mining Area in which some portions of the terrain dropped off steeply or were covered by impenetrable and toxic vegetation (poison oak), male flight activity and female burrows were located haphazardly. We avoided areas which could not be surveyed without creating greater disturbance (i.e., noise) and those areas with extremely steep topography. We tagged female burrows within the Future Mining Area with Garmin Global Positioning System (GPS V) to later be excavated for larval collection and frass analysis.

To determine plant cover association, we used $1 \mathrm{~m}^{2}$ quadrats to visually estimate the percent cover of each plant species found in regions of known occurrence and unobserved occurrence of Mount Hermon June Beetles (Sutherland 1996). Eighteen of these quadrats were placed in areas where the Mount Hermon June Beetlewere known to occur (in areas adjacent to where burrow sites were found, $\leq 80 \mathrm{~m}$ from burrow plots). For comparison, twentysix randomly stratified quadrats were place in areas where neither matings between male and female Mount Hermon June Beetle's nor flight of males were observed but may have occurred (see Fig. 3 for known and unobserved areas).

To further understand the potential requirement and presence of Pinus ponderosa in the Mount Hermon June Beetle habitat as had been specified by prior conservation management for the species, the distance between each female burrow site and the nearest mature Pinus ponderosa was measured. 


\section{Feeding analysis}

Previously tagged female Mount Hermon June Beetle burrows were excavated to a depth of $1 \mathrm{~m}$ in late spring (June 2005) and late summer (September 2005) of the year following summer observations to recover beetle larvae, (in their 3rd or 4th instar) that were least $2 \mathrm{~cm}$ long and easily identified. Frass was collected from captured beetle larvae by placing them in a screen covered vial (to allow for air circulation) in a warm dark place for up to $6 \mathrm{~h}$ or until individuals deposited at least 1 frass pellet. Collected frass pellets were stored frozen for later microscope analysis. Because the larvae are morphologically indistinguishable from co-occuring Polyphylla larvae, DNA analysis was used to distinguish the species from one another. Larvae from which a frass sample was collected were preserved in 95\% ethanol for later DNA analysis. We analyzed frass to identify larval host plant(s). The identifying features of plants within each fecal pellet were recorded. Sample plants were also gathered from the field site, pulverized, and used as reference material.

\section{Larval identification}

To confirm that frass analyzed was from Mount Hermon June Beetle (and not any other co-occuring species), we analyzed larval DNA for each larvae that produced frass using the ITS2 ribosomal gene region, as it is known to be a rapidly evolving gene region and is applicable to a wide range of invertebrate taxa (Slaney and Blair 2000).

In total, tissue from ten larval and three comparison adult beetles captured from the field site was used for DNA analysis. The three adult beetles were two Polyphylla decemlineata and one Polyphylla barbata. The two Polyphylla decemelineata adult tissue samples were collected for comparison from the Future Mining Area of Quail Hollow Quarry and from Riverside County's San Jacinto Mountains.

Five of the ten larvaes' body tissue degraded after being placed in ethanol, reducing the potential overall yield from the DNA analysis. DNA was successfully extracted from five of the ten larvae by using portions of maxillary palps and tarsal segments. Partial fragments of the ITS2 (internal transcribed spacer region 2 of the nuclear ribosomal DNA) were sequenced to differentiate the species. Preserved tissue samples were macerated and incubated with proteinase-K and $5 \%$ Chelex solution at $55^{\circ} \mathrm{C}$ for $1 \mathrm{~h}$ followed by incubation at $100^{\circ} \mathrm{C}$ for $8 \mathrm{~min}$. Primers used to generate partial fragments of the nuclear ITS2 region were ITS2-55 and R2 (5' TGT GAA CTG CAG GAC ACA TG $3^{\prime}$ and $5^{\prime}$ TCT CGC CTG CTC TGA GGT 3', respectively). Fragments were amplified by PCR (polymerase chain reaction) in a total volume of $21 \mu \mathrm{l}(11.2 \mu \mathrm{l}$ deionized water, $2.0 \mu \mathrm{l}$ $10 \times$ PCR buffer, $0.4 \mu \mathrm{l} 10 \mathrm{mM}$ dNTP mixture, $0.5 \mu \mathrm{l}$ of each primer, $4 \mu \mathrm{l} \mathrm{Q}$ (betane) solution, $2 \mu \mathrm{l}$ template DNA, and $0.5 \mu \mathrm{l}$ Taq DNA polymerase). PCR amplification was performed in a CycleLR Genomyx thermal cycler. The mixture was incubated at $95^{\circ} \mathrm{C}$ for 3 min for initial denaturation, followed by 30 cycles of $94^{\circ} \mathrm{C}$ for $45 \mathrm{~s}$, primers annealing for $45 \mathrm{~s}$ at $55^{\circ} \mathrm{C}$, and extension at $72^{\circ} \mathrm{C}$ for $1 \mathrm{~min}$. This was followed by an end run of $7 \mathrm{~min}$ at $72^{\circ} \mathrm{C}$ to complete elongation. Amplification products were visualized by electrophoresis in a $1 \%$ agarose gel in a $1 \times$ TAE bromide $\left(0.5 \mu \mathrm{g} \mathrm{m}^{-1}\right)$. Purified PCR products were sequenced on San Diego State University's ABI Prism ${ }^{\circledR}$ 3100 Genetic Analyzer (Applied Biosystems) using Big Dye Terminator ${ }^{\circledR}$ Chemistry, version 3.1. All sequences were compared for positive species identification of the Mount Hermon June Beetle.

\section{Data analyses}

\section{Habitat description}

To determine the Mount Hermon June Beetle's association with Zayante Sandhills plants, we compared the percent cover of different plant species for terrain type (burrow, known flight region, or unknown occurrence). In inferential analyses terrain type was treated as the independent variable and percent cover for each plant species were treated as dependent variables. Data were first standardized with $\mathrm{z}$-scores to meet the requirements of normality. Multivariate analysis of variance (MANOVA) scores were adjusted for multiple comparisons using post hoc Bonferroni analysis to reduce the risk of a Type 1 error. Analyses were completed using SPSS statistical software (SPSS 1999).

\section{Feeding analysis}

Of the twelve larvae excavated, six produced frass that was stored in sterile containers and frozen for later identification. We first prepared slides of freshly collected plant root tissue that were macerated in preparation for comparative microscopic examination. For easier comparisons between frass and potential host plant, micrographs (photographic images created with a microscope) were taken of frass pellet material at $100 \times$ to $400 \times$ magnification. Analysis of plant fragments in the frass included identification of plant structural elements including cell walls, vessel elements, pits, fiber, trichomes and other structural elements that could be identified within frass pellets on a microscope slide. The frass pellets were further analyzed by a plant anatomist for confirmation of plant tissues and other materials (e.g., fungus). Materials that did not polarize when exposed to a microscopic polarizing lens were treated with a chitin indicator stain, lactophenol cotton blue. 


\section{Results}

Habitat description

A total of 18 Mount Hermon June Beetle mated females and their burrows were located within the Future Mining Area of Quail Hollow Quarry (9 in 2004, 10 in 2005). During nights of mating observations, temperatures ranged from $12-21^{\circ} \mathrm{C}$; wind speeds from $0-13 \mathrm{kph}$. Male beetles were observed to fly and mate under clear and cloudy skies ( 0 to $90 \%$ cloud cover) between the hours of 20:30 and 21:45. The aerial photograph in Fig. 2 indicates areas where burrow were found (outlined in yellow) within the Future Mining Area. The areas in which Mount Hermon June Beetles were observed to occur and not occur are highlighted in Fig. 3.

Overall, the Mount Hermon June Beetle is found within a variety of vegetation within the Future Mining Area; plant species types and abundances varied among burrow sites (see Table 1). In total, $621 \mathrm{~m}^{2}$ plots of vegetation were utilized for comparison (burrow $n=18$, known flight region $n=18$, unknown $n=26$ ). Sixteen plant species were found within the burrow sites. Nineteen plant species were found in the male Mount Hermon June Beetle flight regions and 23 plant species were found in areas where Mount Hermon June Beetles were not observed.

A one way MANOVA revealed significant differences in the percent cover of vegetation between burrow sites, flight regions, and unknown regions (MANOVA: Wilks' Lambda $=0.349 ; d f=36,84 ; P=.038$ ). Given the significance of the overall test, the univariate main effects were examined. Post hoc Bonferroni analyses revealed significant differences for the percentage of bare ground found in burrow sites and known flight regions, $F(36,84)$ $=1.614 P<.01$, and burrow sites and unknown regions, $F(36,84)=1.614, P<.05$, with the highest percentage of bare ground occurring in burrow plots. The eighteen $1 \mathrm{~m}^{2}$ burrow sites averaged $49 \%$ bare ground whereas the sampled male Mount Hermon June Beetle flight regions averaged $16 \%$ bare ground, and areas Mount Hermon June Beetles were not observed averaged 25\% bare ground (Fig. 4).

Cover of Chorizanthe pungens var. hartwegiana was greater in burrow plots than in sites where the Mount Hermon June Beetle were not observed. Post hoc Bonferroni analysis revealed significant differences between the proportions of Chorizanthe pungens var. hartwegiana found in female burrow sites and sites where Mount Hermon June Beetles were not observed, $F(36,84)=1$. $614, P<.04$, but not between female burrow sites and Mount Hermon June Beetle flight regions or Mount Hermon June Beetle flight regions and areas where Mount Hermon June Beetles were not observed (Fig. 4). However, Chorizanthe pungens var. hartwegiana was found in only four burrow sites in percentages of $6,13,25$, and 36 . The Mount Hermon June Beetles were associated with a subset of the Zayante Sandhills plant assemblage, but other than Chorizanthe spp. mentioned above, were not distinctly associated with native Zayante Sandhills species.

Lastly, the mean distance between female burrows and the nearest Pinus ponderosa was $38.03 \mathrm{~m}$ (SD $42 \mathrm{~m}$ ).

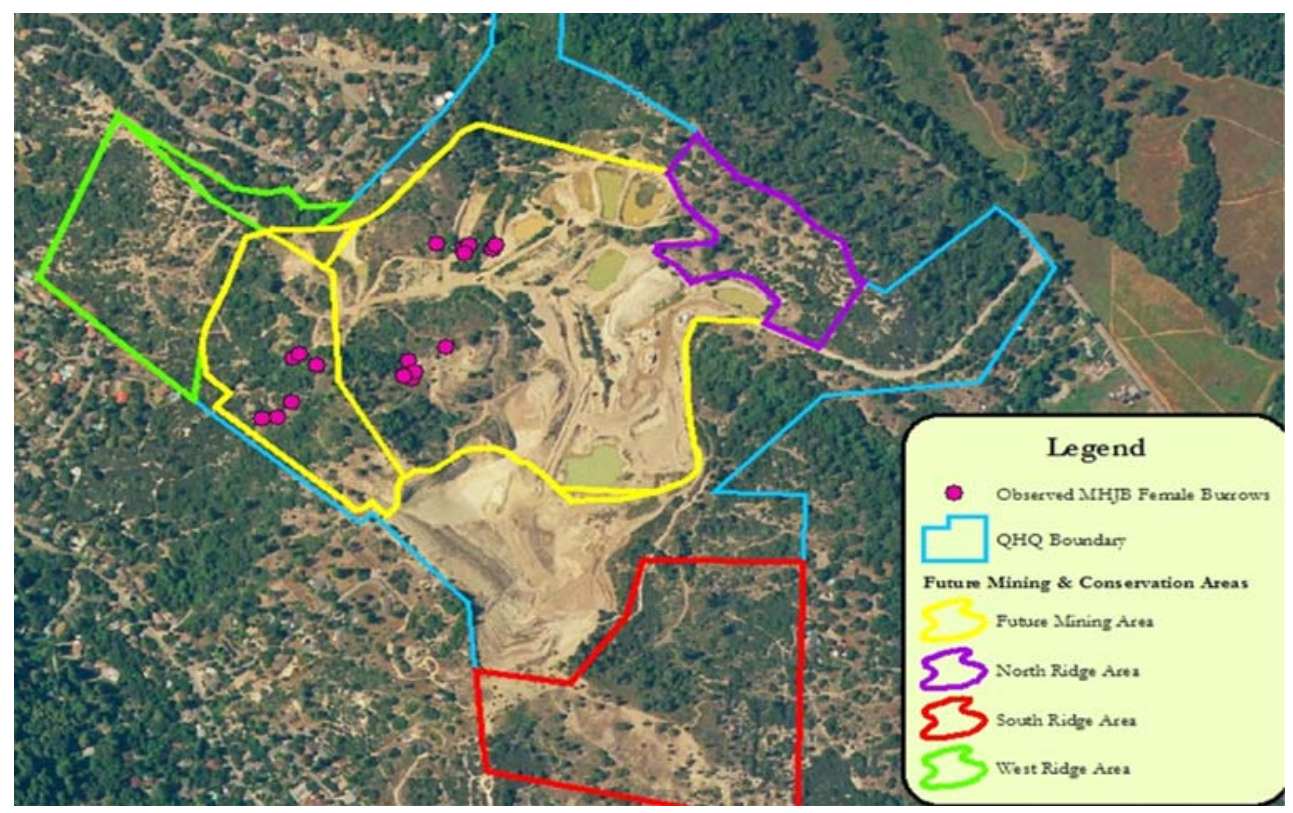

Fig. 2 Location of female Mount Hermon June Beetle burrows within the Future Mining Area 


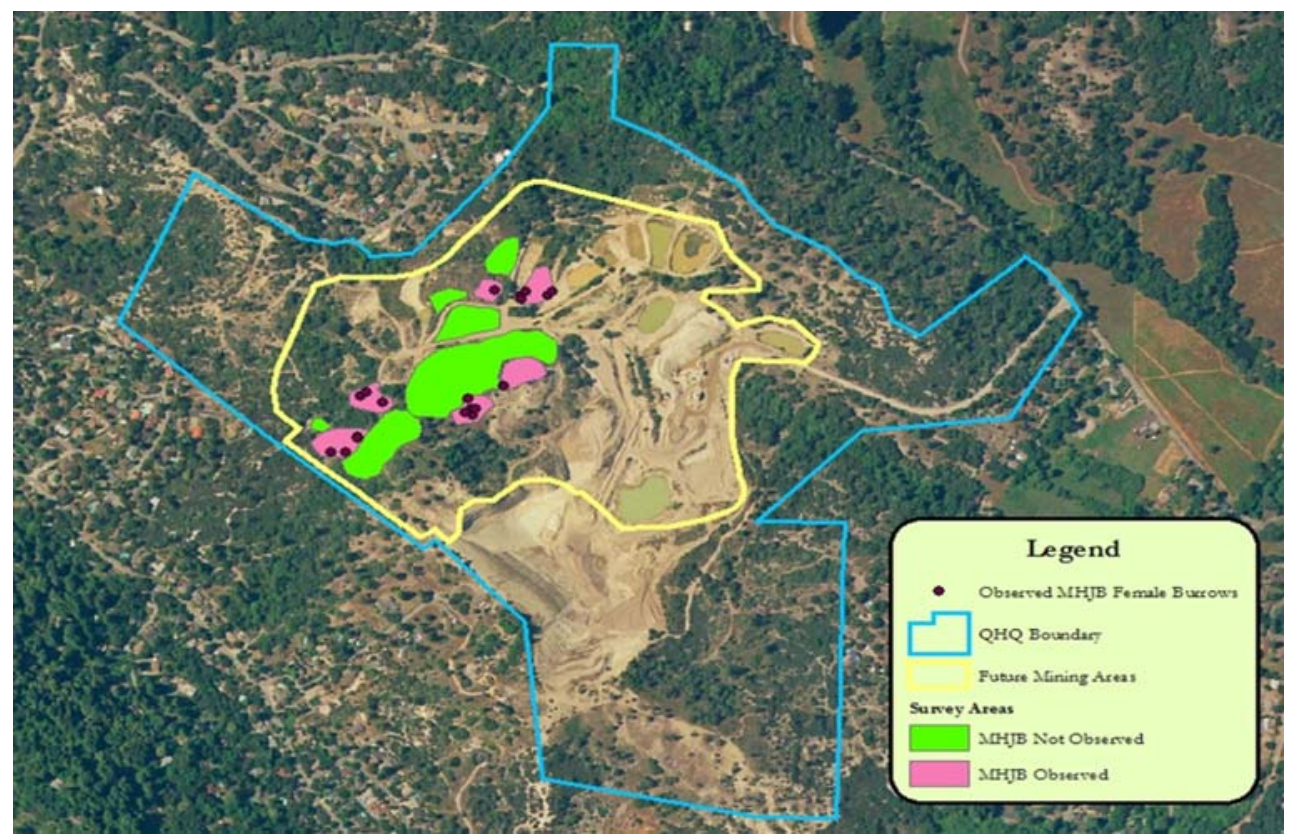

Fig. 3 Surveyed areas within the Future Mining Area

Table 1 Percent cover of each plant species per site type

\begin{tabular}{|c|c|c|c|c|c|c|}
\hline \multirow[t]{2}{*}{ Plant species } & \multicolumn{2}{|c|}{ Burrow $(n=18)$} & \multicolumn{2}{|c|}{ MHJB flight regions $(n=18)$} & \multicolumn{2}{|c|}{ MHJB not observed $(n=26)$} \\
\hline & Mean & SD & Mean & SD & Mean & SD \\
\hline Arbutus menziesii & 0.00 & 0.00 & 0.00 & 0.00 & 2.15 & 10.20 \\
\hline Arctostaphlyos tomentosa & 0.00 & 0.00 & 0.00 & 0.00 & 6.04 & 21.32 \\
\hline Baccharus pilularis & 0.00 & 0.00 & 0.60 & 2.53 & 8.38 & 25.02 \\
\hline Bare ground ${ }^{\mathrm{a}}$ & 49.33 & 30.96 & 16.49 & 29.40 & 25.23 & 33.94 \\
\hline Ceanothus cuneatus & 1.44 & 6.13 & 9.18 & 26.27 & 3.85 & 19.61 \\
\hline Chorizanthe pungens var. hartwegiana ${ }^{\mathrm{b}}$ & 4.44 & 10.21 & 0.26 & 1.12 & 0.03 & 0.13 \\
\hline Ericameria ericoides & 1.77 & 5.82 & 7.22 & 19.16 & 0.50 & 2.55 \\
\hline Eriodictum californica & 0.44 & 1.34 & 0.11 & 0.47 & 0.73 & 3.34 \\
\hline Eriogonum nudum & 4.83 & 20.01 & 0.07 & 0.21 & 0.04 & 0.20 \\
\hline Lotus scoparius & 5.24 & 7.53 & 9.42 & 20.74 & 6.38 & 16.20 \\
\hline Lupinus chamissonis & 0.17 & 0.71 & 0.17 & 0.71 & 4.67 & 13.33 \\
\hline Mimulus aurantiacus & 6.36 & 14.97 & 3.67 & 7.71 & 1.88 & 5.11 \\
\hline Moss & 1.28 & 3.68 & 0.53 & 2.24 & 1.73 & 8.83 \\
\hline Other* & 2.30 & 4.05 & 0.50 & 0.79 & 4.42 & 16.00 \\
\hline Pinus ponderosa & 0.00 & 0.00 & 0.00 & 0.00 & 9.42 & 27.86 \\
\hline Poaceae & 20.76 & 36.95 & 34.11 & 42.81 & 21.58 & 34.61 \\
\hline Pteridium aquilinum & 1.06 & 3.30 & 5.81 & 21.39 & 0.23 & 1.18 \\
\hline Salvia mellifera & 0.58 & 2.48 & 5.56 & 23.57 & 1.77 & 9.02 \\
\hline
\end{tabular}

* Includes Eschoscholzia californica, Gnaphalium sp., Hamata sp., Heterotheca grandifolia, Holocarpha sp., Lessingia filaginifolia var. filaginifolia and dead wood

${ }^{a}$ Significant differences between burrow sites, flight regions, and sites where MHJB were not observed $(P=.009)$

${ }^{\mathrm{b}}$ Significant differences between burrow sites and sites where MHJBs were not observed $(P=.034)$

Eleven burrows were found to be within $26 \mathrm{~m}$ (i.e., below the mean distance) from the nearest Pinus ponderosa. Six female burrows found between 50 and $59 \mathrm{~m}$ from nearest
Pinus ponderosa. Two female burrows were found between 134 and $137 \mathrm{~m}$ from nearest Pinus ponderosa (Fig. 5). 

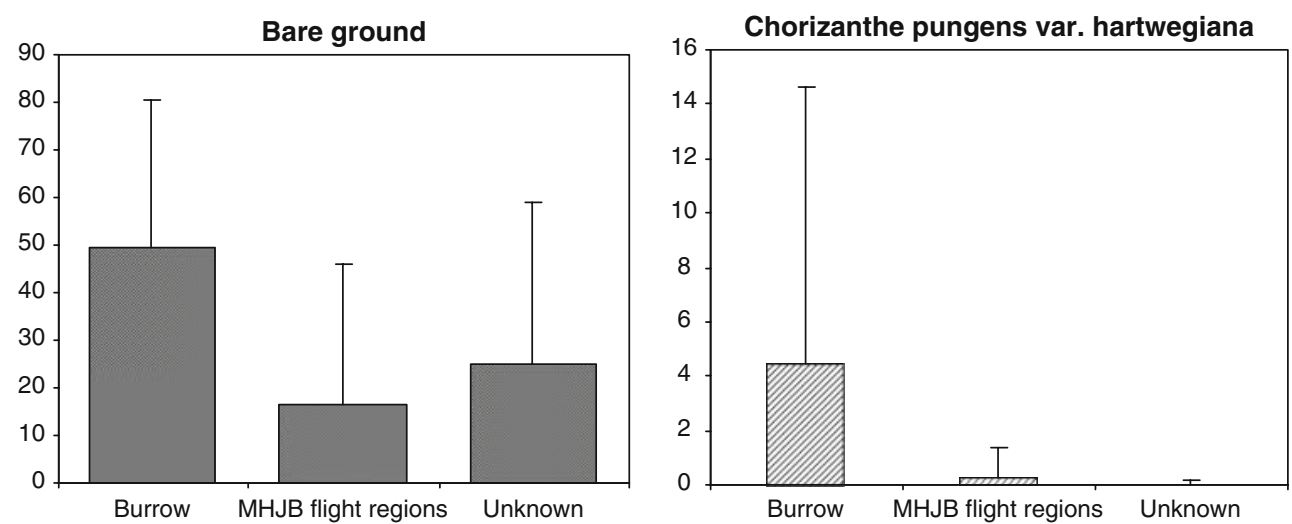

Fig. 4 Differences between terrain types for one plant species and bare ground

Feeding analysis

DNA analysis of the five larvae successfully sampled identified all to be Polyphylla barbata with no intra-population variation for the ITS2 gene sequence. The Polyphylla barbata populations differed from the Polyphylla decemlineata populations sampled by eight base pairs and three base insertions. The larval gene sequence was placed in GenBank, Accession number: GU137294. One sample of larval frass for which DNA analysis of the larva was unsuccessful, was included in analysis here because it was found in the same burrow, very close to a larva that was successfully identified as a Mount Hermon June Beetle (see Table 2).

Within six frass pellets, a plant anatomist identified materials indicative of angiosperms and fungi. Frass pellet 6 contained anatomical features, that when found in combination, are unique to Pteridophyta and primitive plants. These features included scalariform pitting and vessel elements. This pellet also contained trichomes which are found on plant stems and were possibly indicative of the larva feeding on underground stem portion of the plant.

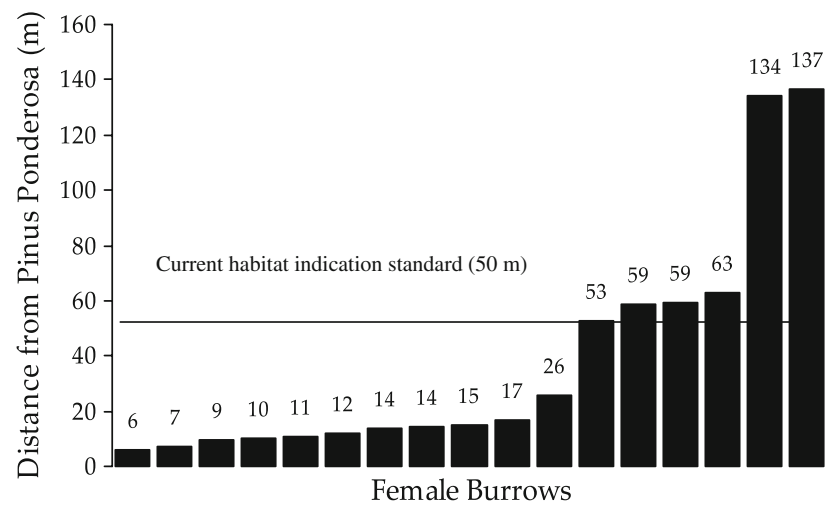

Fig. 5 Distance in meters from nearest Pinus ponderosa to female Mount Hermon June Beetle burrow locations
Within frass pellets 2, 3, and 6 were identified angiosperm material indicative of primary growth, including vessel elements, tracheary elements, pitted elements, and circular and helical xylem. Within frass pellets 2, 5, and 6 were identified fibers and multicellular and branched hairs. Multicellular hairs are typically found on stems of plants; branched and multicellular hairs could also indicate underground portions of stems or rhizomes. (Fig. 6 and Table 2). Much of these materials (4 of the 5 pellets) were indicative of primary non-woody growth and all materials are indicative of angiosperms. Material that did not polarize under a polarizing lens was positively identified as fungal hyphae in three frass pellets (Fig. 7).

\section{Discussion}

Results of this study indicate that Mount Hermon June Beetle is not a feeding specialist but is a microhabitat specialist. Frass analysis revealed that larvae consumed angiosperm plants as well as mycorrhizal fungus, a rich source of protein. As generalist insects, the Mount Hermon June Beetle larvae may have an advantage over specialists in that they are often completely opportunistic, eating largely what is most commonly available. They can make use of several different host plants when the nutrient availability is low or when ingested plant toxins from one food source need to be diluted. As generalists, they are most limited in host plant selection by the presence of plant secondary compounds or deterrents (Renwick 2001). Pteridium aquilinum, an abundant fern at two of the burrow sites where larvae were found, was indicated in their frass. Pteridium aquilinum is known to contain secondary compounds and chemicals that may interfere with insect growth (Jones and Firn 1978). Despite this, Pteridium aqulinum is host to many insect species worldwide. Analysis of additional larval frass samples would likely reveal a wider diet. 
Table 2 Frass analysis, plant and mycorrhizal structures identified

\begin{tabular}{|c|c|c|c|}
\hline $\begin{array}{l}\text { Larval DNA } \\
\text { identifier }\end{array}$ & $\begin{array}{l}\text { Frass } \\
\text { pellet }\end{array}$ & Structural elements identified & Conclusion \\
\hline S669a & 1 & Fungal structures & Mycorrhizae \\
\hline S669b* & 2 & Bordered pits with oval apertures, helical elements, multicellular branched hair & Angiosperm \\
\hline S671 & 3 & $\begin{array}{l}\text { Non-woody herbaceous material. No periderm, no wood present. Circular xylem present. } \\
\text { Primary growth indicated by vessel elements present. Pitted elements and multicellular } \\
\text { hairs. }\end{array}$ & Angiosperm \\
\hline S672 & 4 & Possible root cells, wood and xylem, fungal structures & Angiosperm, mycorrhizae \\
\hline S673 & 5 & Fibers, fungal structures & $\begin{array}{l}\text { Angiosperm stem } \\
\text { structure, mycorrhizae }\end{array}$ \\
\hline S692 & 6 & $\begin{array}{l}\text { Trichomes, xylem, helical elements, multicellular hairs, scalariform pitting, vessel } \\
\text { elements, pitted elements }\end{array}$ & $\begin{array}{l}\text { Possibly Pteridium } \\
\text { aquilinum }\end{array}$ \\
\hline
\end{tabular}

* This larva was collected from the same burrow site as S669a but DNA identification was not possible

Host plant theory posits that among all types of insects, related species of insects commonly are specialized to feed on related plants (Bernays 1998; Ehrlich and Raven 1964; Futuyma 2000; Scriber 2002). Most Polyphylla species feed on the roots of many plants, and larvae are found in association with sandy soils (Young 1988). Several other Polyphylla species are known to be economic pests, feeding on the roots of fruit trees, and as adults feeding on the leaves of forest trees such as elm, maple and oak. Insects may have genetic variation for characteristics required to shift to some plant species, but lack genetic variation to shift to other plants and they are more likely to shift to certain potential novel hosts over others as they increase their range and face new potential food sources (Futuyma 1995, 2000). Polyphylla decemelineata, the Mount Hermon June Beetle's sympatric congener, and an economic pest in parts of central and southern California, is also said to feed on the needles of ponderosa pine trees as an adult (Evans and Hogue 2004). Given that many Polyphylla are evidenced to be generalists, it is feasible that the Mount Hermon June Beetle feeds on several host plants within the Sandhills.

The Mount Hermon June Beetle was not limited to undisturbed soils. Burrows were found in areas where native disturbance-adapted species such as Heterotheca grandiflora proliferated. Vegetation in areas where Mount Hermon June Beetle matings were observed consisted of anthropogenically degraded parkland silver-leaf manzanita mixed chaparral with Pinus ponderosa, and a mélange of assemblages (Jodi McGraw, pers.comm 7/12/2005). All but four burrow $(n=18)$ sites that were found in the relatively intact area of the far side of the Future Mining Area were found in degraded Sandhills habitat. However, as there was an association between the burrow locations and the percentage of bare ground, this indicates that this feature of the Sandhills landscape may be important in at least the June Beetle's mating season. One of the distinguishing features of the Sandhills habitat is its parkland, which is characterized by an open and sparsely vegetated understory interspersed with Ponderosa pine trees. This open canopy is maintained by the naturally fire adapted community and supports endemic species like Chorizanthe pungens var. hartwegiana. However, as the beetles were also found in areas of dense grass stands and near thickets of trees and chaparral, the openness of the parkland community in the Sandhills does not preclude other vegetative communites within the Sandhills, including weedy areas, or areas of moderate anthropogenic impact as June Beetle habitat.

As stated earlier, in conservation management, Pinus ponderosa has been used as an indicator of Mount Hermon June Beetle habitat because unpublished reports suggest that it is a potential host plant of the Mount Hermon June Beetle (Arnold 2004). We could not confirm that Pinus ponderosa was a host plant for larvae in this study. Although many burrows were found near Pinus ponderosa, some observations and female burrows and some collected larvae were also found in locations over $122 \mathrm{~m}$ away from the nearest mature Pinus ponderosa, revealing that the tree is not an important feature of larval development. Because of this finding, it is not advisable to plant Pinus ponderosa in attempt to create or maintain the Mount Hermon June Beetle habitat, as has previously been recommended (draft Long Term Monitoring and Management Plan for Quail Hollow Quarry). Moreover, it is essential that habitat located away from Pinus ponderosa be protected.

The habitat selection criteria of this species could be refined with longer-term studies of vegetation analyses of female burrow sites and male Mount Hermon June Beetle flight regions. In terms of its recovery, it would helpful to understand how the Mount Hermon June Beetle colonizes an area, and particular factors for its recolonization (i.e., proximity to intact/undisturbed area, characteristics of intact area). Further, the Mount Hermon June Beetle could 


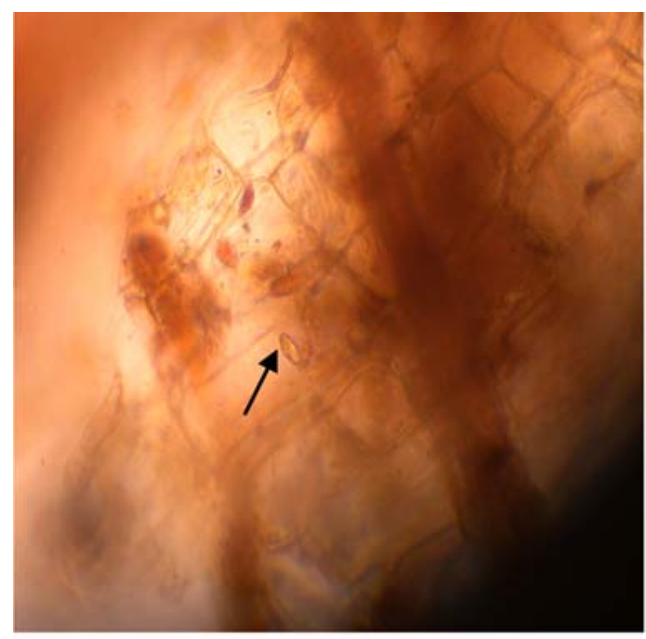

Pellet 2: Bordered pit with oval aperture

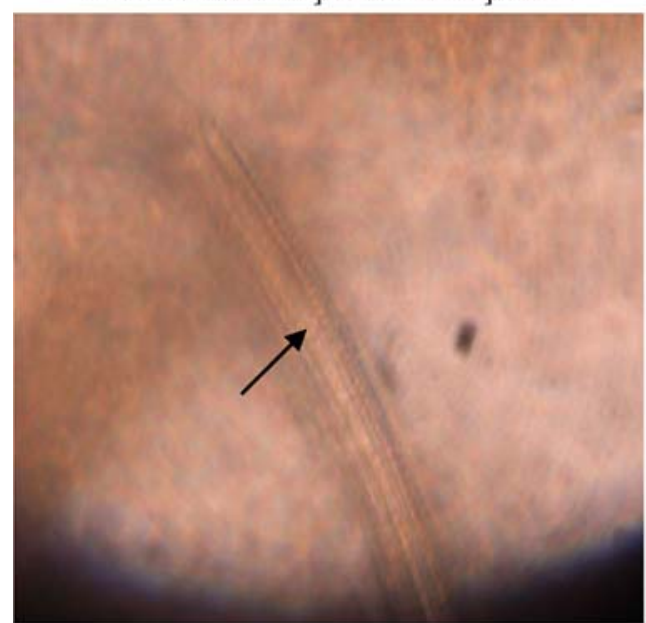

Pellets 3,6: Pitted elements

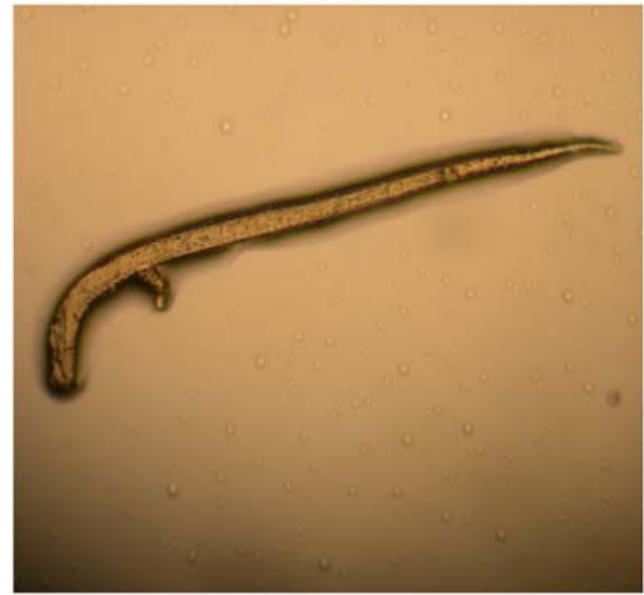

Pellet 6: Trichome

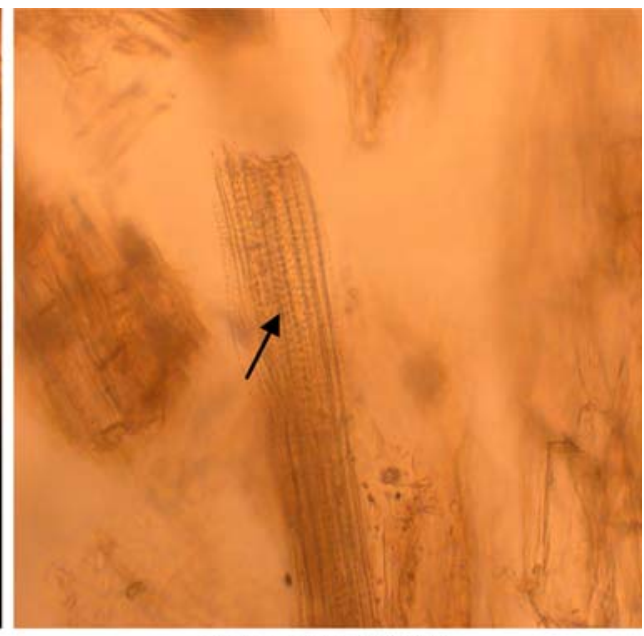

Pellets 3,4,6: Xylem

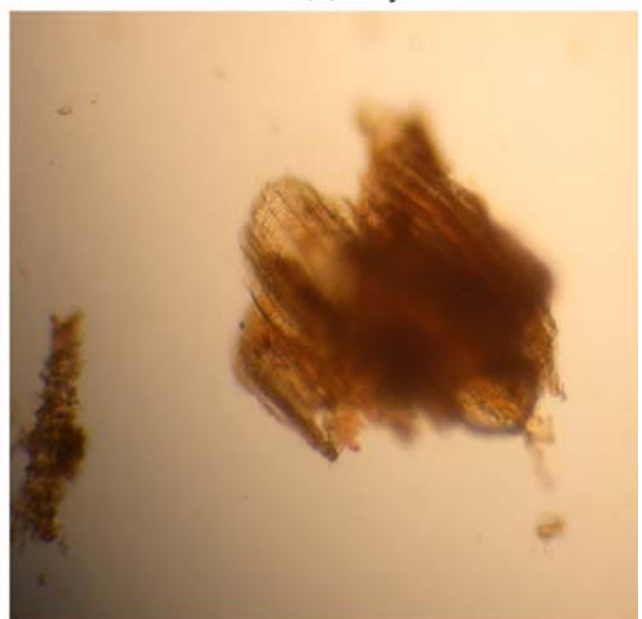

Pellet 4: Possible root cells, xylem

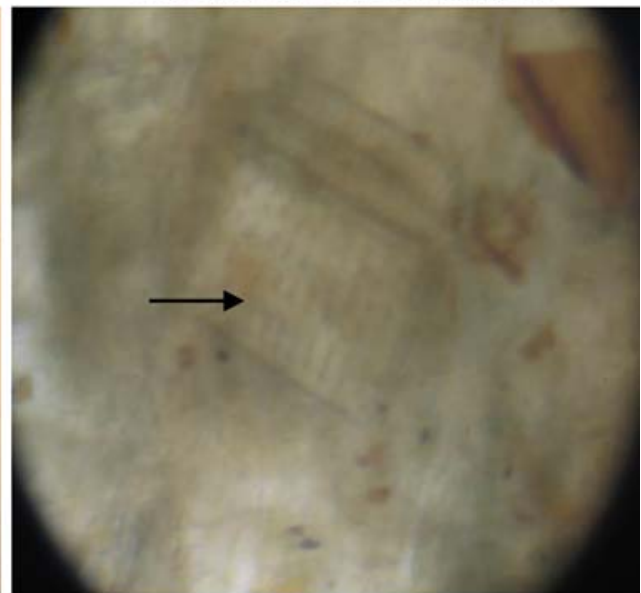

Pellet 6: Scalariform pitting

Fig. 6 Plant features identified within Mount Hermon June Beetle frass pellets

benefit from studies of its relationship to other animal species, including potential parasites and predators. There could be other chemical or ecological factors that may be determining the Mount Hermon June Beetle's bionomics. For example, we observed the June Beetles being preyed upon by bats and beetles walking on the ground surface were often found to have flies crawling on and around them. Males may also be hindered in their pursuit of females by house lights, road way traffic and the complexity of the terrain. 


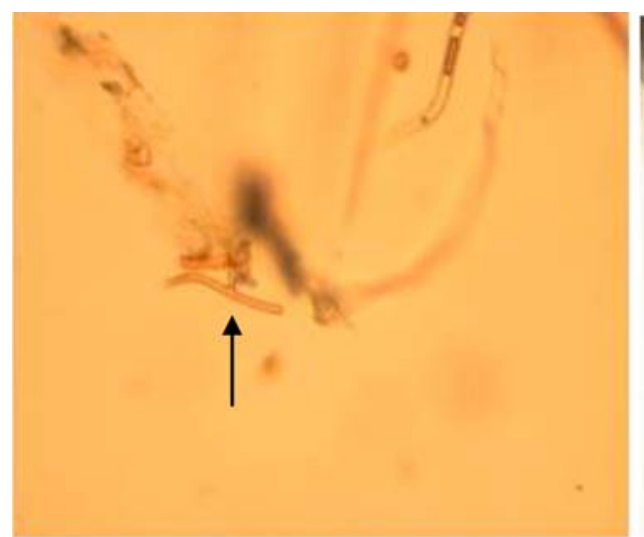

Pellet 1: fungal structures

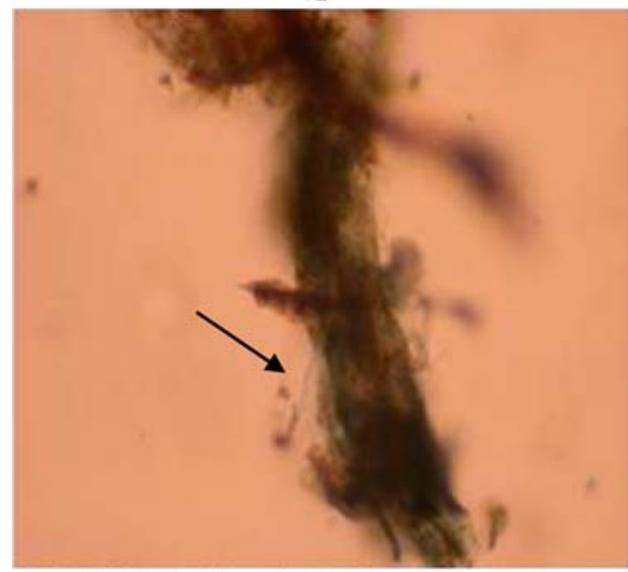

Pellet 4: fungal structures, treated with stain

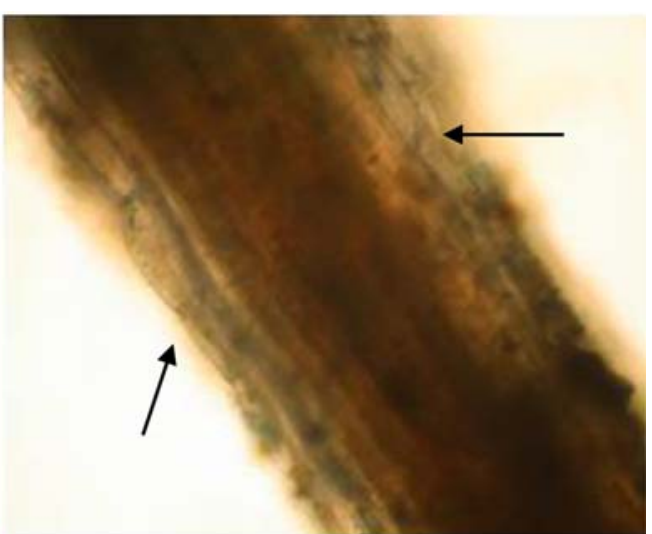

Pellet S: fungal structures, treated with stain

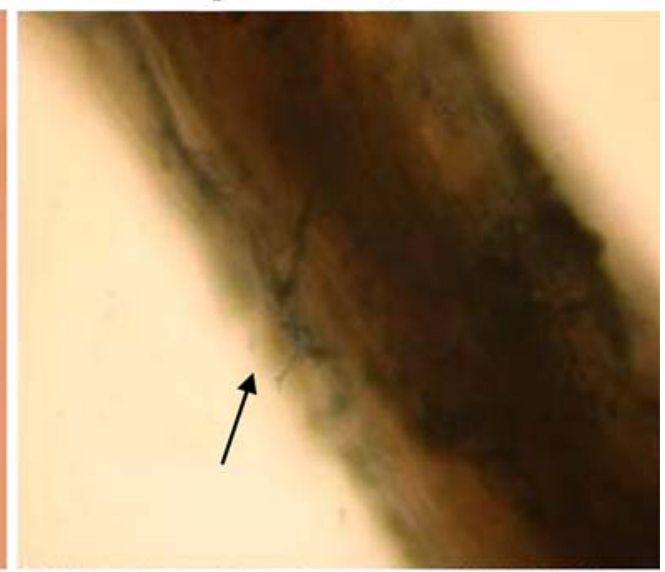

Pellet 5: fungal structures, treated with stain

Fig. 7 Fungal structures identified with Mount Hermon June Beetle frass pellets

Maintenance of Mount Hermon June Beetle habitat by identification of typical microhabitat species associations should help the recovery of the Mount Hermon June Beetle. Data here shows that the species is not limited to one particular host plant species. The sixteen plant species associations found in burrow locations may be indicative of habitat soil disturbance levels and/or food nutritional quality important to the species. Findings from this study would suggest that other features of the habitat may be equally important to its selection criteria, including the high silica content, fine grained, sandy soil that is resultant from the uplift of an ancient Miocene sea bed. This sand is in large part responsible for the uniqueness of the plant assemblages found here. However, because the Mount Hermon June Beetle female is flightless, the population's continued dispersal and survival is limited to the females' ability to burrow through the soil. The genetic fitness of the species may already be compromised by urban and mining developments that may cutoff movement between the fragmented populations within the Sandhills. Population fitness of the species is going to be best ensured through maintaining connectivity of habitat within the intact areas of the Zayante Sandhills, particularly those areas which continue to experience natural disturbance, such as fire regimes that help to maintain characteristic openness. Public education and support for all those involved in the Sandhills recovery is crucial to the protection of this unique and fragile environment.

This study was limited by the small sample sizes (both vegetation and frass) and also by the sites that were defined as areas where Mount Hermon June Beetle was not detected within the Future Mining Area of the Quarry. The terrain within these areas may not have been distinguishable from areas in which the Mount Hermon June Beetle was detected. Areas where the Mount Hermon June Beetle was not detected may, in fact, be habitat for Mount Hermon June Beetle but were simply not detected by observation. Given the number of plots sampled, the study had $80 \%$ power to detect an effect size of 0.73 . It is unknown what effect size is meaningful.

Acknowledgments We would like to thank Richard Arnold, Jeff Honda for their helpful comments on earlier versions of this manuscript. We also thank Jodi McGraw for her help with photos, comments 
on the manuscript and field help. We thank David Bruck for his identification of plant materials within the frass. We also thank Jena Casey, Susan Lambrecht, Monica Nanez, Nicole Rucker, Rebecca Sloan, Bill Reid, Jeff Titler, and Jennifer Chu for their assistance as field scouts. Thanks to Marshall Johnson and David Hawks for providing larval comparisons and assisting with DNA analysis. Roger Root, USFWS provided permits. Thanks also to Mary Power and Andrew Winzelberg.

Open Access This article is distributed under the terms of the Creative Commons Attribution Noncommercial License which permits any noncommercial use, distribution, and reproduction in any medium, provided the original author(s) and source are credited.

\section{References}

Arnett RH, Thomas MC, Skelly PE, Howard Frank J (eds) (2002) American beetles, vol 2: polyphaga: Scarabaeoidea through Curculionoidea. New York, CRC Press

Arnold RA (1999) 1999 Monitoring report for the Mount Hermon June Beetle and Zayante Band Winged grasshopper at Hanson Aggregates' Felton Quarry. Report prepared for Hanson Aggregates Mid-Pacific. Entomological Consulting Services Ltd, Pleasant Hill, CA, $33 \mathrm{p}$

Arnold RA (2004) Mount Hermon June Beetle (Polyphylla barbata Cazier 1938). In: McGraw JM (ed) The Sandhills conservation and management plan: a strategy for preserving native biodiversity in the Santa Cruz Sandhills (Section 5.6 pp 92-99). The Land Trust of Santa Cruz County, Santa Cruz

Bernays EA (1998) The value of being a resource specialist: behavioral support for a neural hypothesis. Am Nat 151(5): $451-464$

Borror DJ, Delong DM, Triplehorn CA (1976) An introduction to the study of insects, 4th edn. Holt, Rinehart, and Winston, San Francisco

Cazier MA (1938) A new California Polyphylla with notes concerning the variability of certain characters within the genus. Pan-Pac Entomol 14:161-164

Connor EF, Hafernik J, Levy J, Moore VL, Rickman JK (2003) Insect conservation in an urban biodiversity hotspot: the San Francisco Bay Area. J Insect Conserv 6:247-259

Ehrlich PR, Raven PH (1964) Butterflies and plants: a study in coevolution. Evolution 18(4):586-608

Evans AV, Hogue JN (2004) Introduction to California beetles. University of California Press, Berkeley

Futuyma DJ (1995) Genetic constraints on macroevolution: the evolution of host affiliation in the leaf beetle genus Ophraella. Evolution 49(5):797-809

Futuyma DJ (2000) Some current approaches to the evolution of plant-herbivore interactions. Plant Species Biol 15:1-9

Granite Rock Company (1998) Revised habitat conservation plan. Granite Rock Company, Watsonville

Griffin JR (1964) Isolated Pinus ponderosa forests on sandy soils near Santa Cruz, California. Ecology 45:410-412
Hazeltine W (1993) Distribution of the scarab beetle Polyphylla barbata Cazier (Unpublished report). Oroville, California

Hazeltine W (1994) Comments for the U.S. Department of Interior, Fish and Wildlife Service, regarding the proposed listing of three species of insects as endangered. In: U.S. Fish and Wildlife Service, U.S. Department of Interior

Jones CG, Firn RD (1978) The role of phytoecdysteroids in bracken fern, Pteridium aquilinum (L.) Kuhn as a defense against phytophagous insect attack. J Chem Ecol 4(2):117-138

Lee D (1994) Management proposal for the inland sandhill habitats of Santa Cruz County, CA. San Jose State University, San Jose, CA (Unpublished master's thesis)

Marangio MS (1985) Preservation study: Sandhills biotic communities of Santa Cruz County, California. University of California, Berkeley (Unpublished master's thesis)

McGraw JM (2004) The Sandhills conservation and management plan: a strategy for preserving native biodiversity in the Santa Cruz Sandhills. The Land Trust of Santa Cruz County, Santa Cruz

O'Malley R, Taylor L, Hill KE (2003) Progress report to the US Fish and Wildlife Service: habitat requirements of the Mount Hermon June Beetle (Polyphylla Barbata): Larval host plants and feeding ecology

Renwick JA (2001) Variable diets and changing taste in plant-insect relationships. J Chem Ecol 27(6):1063-1076

Russell D (1994) Summary of Mount Hermon Beetle surveys and analysis of species distribution (Unpublished report). Miami University, Oxford

Scriber JM (2002) Evolution of insect-plant relationships: chemical constraints, coadaptation, and concordance of insect/plant traits. Entomol Exp Appl 104:217-235

Slaney DP, Blair D (2000) Molecules and morphology are concordant in discriminating among populations of cave cockroaches in the genus Paratemnopteryx Saussure (Blattodea: Blatellidae). Ann Entomol Soc Am 93(3):398-404

SPSS Inc. (1999) SPSS Base 11.0 for window's user's guide. SPSS Inc., Chicago

Sutherland WJ (1996) Ecological census techniques: a handbook. Cambridge University Press, New York

U.S.D.A. Soil Conservation Sciences (1980) Soil survey of Santa Cruz County, California

U.S. Fish and Wildlife Service (1997) Endangered and threatened wildlife and plants; determination of endangered status for two insects from the Santa Cruz Mountains of California: federal register

U.S. Fish and Wildlife Service (1998) Recovery plan for insect and plant taxa from the Santa Cruz Mountains in California. Portland, Oregon

Van Steenwyk RA, Rough D (1989) Biology of the tenlined June Beetle (Coleoptera:Scarabaeidae). J Econ Entomol 82:1738-1742

Young RM (1967) Polyphylla Harris in America, North of Mexico. Part I: the Diffracta complex (Coleoptera: Scarabaeidae: Melolonthinae). Trans Am Entomol Soc 93:279-318

Young RM (1988) A monograph of the genus Polyphylla Harris in America North of Mexico (Coleoptera: Scarabaeidae: Melolonthinae). Bull Univ Nebr State Mus 11(2):1-106 